\title{
Influence of the soil from Oxytree [Paulownia elongata \\ S. Y. Hu $\times$ Paulownia fortunei (Seem.) Hemsl.] plantation on germination and initial growth of winter wheat and winter rape
}

\author{
Wpływ gleby pobranej z plantacji Oxytree [Paulownia elongata \\ S. Y. Hu $\times$ Paulownia fortunei (Seem.) Hemsl.] na kiełkowanie \\ i początkowy wzrost pszenicy ozimej i rzepaku ozimego
}

\author{
Marcin Bortniak, Tomasz R. Sekutowski, Olga Zajączkowska, Mariusz Kucharski*
}

\section{Summary}

The aim of the study was to determine the influence of soil from Oxytree [Paulownia elongata S. Y. Hu $\times$ Paulownia fortunei (Seem.) Hemsl.] root zone on germination and initial growth of winter wheat and winter rape. The soil samples were taken from one and two years old plantation. The experiments were conducted using Phytotoxkit ${ }^{\mathrm{TM}}$ bioassay and the results showed a lack of statistically significant allopathic effect of Oxytree (regardless of age of plantation) on tested plants. However, slightly stimulation of winter wheat roots and coleoptile growth and inhibition of winter rape roots length were observed.

Key words: Oxytree; paulownia; soil; seed germination; phytotoxicity; bioassay

\section{Streszczenie}

Celem pracy była ocena wpływu gleby pochodzącej z warstwy korzeniowej drzew Oxytree [Paulownia elongata S. Y. Hu $\times$ Paulownia fortunei (Seem.) Hemsl.] na kiełkowanie i początkowy wzrost pszenicy ozimej i rzepaku ozimego. Glebę pobrano z rocznej i dwuletniej plantacji Oxytree. Doświadczenie przeprowadzone przy użyciu biotestu Phytotoxkit ${ }^{\top M}$ nie wykazało allelopatycznego wpływu Oxytree na rośliny testowe, niezależnie od wieku plantacji (roczna lub dwuletnia). Zaobserwowano stymulację wzrostu korzeni i koleoptyli pszenicy ozimej na glebach spod Oxytree oraz zahamowanie długości korzeni rzepaku, jednak wartości te (podobnie, jak pozostałe mierzone parametry) nie różniły się statystycznie od wyników uzyskanych dla obiektów kontrolnych.

Słowa kluczowe: Oxytree; paulownia; gleba; kiełkowanie nasion; fitototoksyczność; test biologiczny

*corresponding author: m.kucharski@iung.wroclaw.pl 


\section{Wstęp / Introduction}

Oxytree (Paulownia Clon in Vitro 112 ${ }^{\circledR}$ ) określane również mianem drzewa tlenowego, to roślina powstała $\mathrm{w}$ wyniku skrzyżowania i klonowania w warunkach laboratoryjnych dwóch gatunków Paulowni - Paulownia elongata i Paulownia fortunei, przez hiszpańską firmę biotechnologiczną In Vitro S.L. z Sant Feliu de Llobregat, Barcelona (numer identyfikacyjny szkółki ES-09-08-0016) (Raport 2013). Klon ten charakteryzuje się niezwykle silnym przyrostem biomasy, osiągając w wieku 6 lat wysokość 16 metrów. Głównym kierunkiem uprawy Oxytree jest pozyskanie drewna, które jest wysokiej jakości surowcem, wykorzystywanym m.in. w budownictwie, do produkcji mebli, do budowy jachtów czy desek surfingowych. Pierwsze plantacje w Europie zostały założone ponad 10 lat temu w Hiszpanii, a w kolejnych latach również w Rumunii, Słowenii, Austrii, Czechach i na Węgrzech. W roku 2015 została założona pierwsza plantacja w Polsce i od tego czasu ich liczba ciągle wzrasta (http://oxytree.pl).

Wprowadzanie nowych organizmów może nieść za sobą ryzyko ich niekontrolowanego przeniknięcia do środowiska i negatywnego wpływu na inne gatunki. W obrębie rodziny paulowniowatych (Paulowniaceae) znajduje się, uznana za gatunek inwazyjny, spokrewniona z Oxytree - paulownia omszona (Paulownia tomentosa). Według zapewnień producenta Oxytree może rozmnażać się jedynie wegetatywnie, co praktycznie wyklucza jej inwazyjność (http://oxytree. pl). Brakuje jednak wieloletnich doświadczeń in situ realnie oceniających ryzyko przyrodnicze uprawy tych roślin, przeprowadzonych przez niezależne jednostki naukowo-badawcze, co zostało zaakcentowane w opinii Państwowej Rady Ochrony Przyrody (PROP/KOR/2016-01-ws).

Wzajemne oddziaływanie allelopatyczne między roślinami jest powszechnie znanym zjawiskiem, a wytwarzane przez te rośliny substancje allelochemiczne obejmują całą gamę związków organicznych. Jednym ze sposobów uwalniania allelopatyn do środowiska glebowego jest wydzielanie przez system korzeniowy (eksudacja) (Gniazdowska i wsp. 2004). Pomimo zasięgu ograniczonego wyłącznie do ryzosfery, eksudacja może odgrywać istotną rolę w wywieraniu inhibicyjnego lub stymulacyjnego działania na rozwój i wzrost roślin sąsiadujących (Fernandez-Aparicio i wsp. 2008; Al-Sherif i wsp. 2013).

Celem przeprowadzonych badań była ocena wpływu gleby pobranej z warstwy korzeniowej Oxytree, pochodzącej z 1-rocznych i 2-letnich roślin, na kiełkowanie i początkowy wzrost pszenicy ozimej i rzepaku ozimego.

\section{Materiały i metody / Materials and methods}

Mikrobiotest Phytotoxkit ${ }^{\mathrm{TM}}$ jest szybkim testem opartym na pomiarach zdolności kiełkowania nasion roślin testo- wych i szybkości wzrostu korzeni. Służy on do wykrywania substancji o charakterze ksenobiotyków znajdujących się w glebie lub osadach. Szybkość uzyskania wyników (nawet już po upływie 3-5 dni od założenia biotestu) oraz łatwość wykonywania pomiarów dzięki wykorzystaniu metody analizy obrazu Image Tools pozwoliły na wykorzystanie Phytotoxkit ${ }^{\mathrm{TM}}$ do wykrywania pozostałości substancji czynnych herbicydów w glebie (Sekutowski i Sadowski 2009) lub potencjału allelopatycznego roślin (Bortniak i Sekutowski 2009; Marczewska-Kolasa i wsp. 2012).

Doświadczenie prowadzono $\mathrm{w}$ warunkach laboratoryjnych, wykorzystując zmodyfikowany test kiełkowania i wczesnego wzrostu roślin - Phytotoxkit ${ }^{\mathrm{TM}}$ (Phytotoxkit 2004). Glebę do badań pobierano $\mathrm{z}$ warstwy $30 \mathrm{~cm} \mathrm{w}$ bezpośrednim otoczeniu bryły korzeniowej, z 1-rocznej (G-2) i 2-letniej (G-3) plantacji Oxytree. Na każdej plantacji pobrano próbkę zbiorczą spod losowo wybranych 10 roślin. Obiekt kontrolny (G-1) stanowiła gleba pochodząca $\mathrm{z}$ obszaru pola niebędącego zajętym pod uprawę Oxytree. $\mathrm{Z}$ uwagi na sposób wysadzania roślin wraz z podłożem hodowlanym, gleba pobrana do badań stanowiła mieszaninę, której charakterystykę zamieszczono w tabeli 1. Płytki biotestu Phytotoxkit ${ }^{\mathrm{TM}}$ wypełniono poszczególnymi glebami w ilości $90 \mathrm{ml}$ na płytkę i nasączono $10 \mathrm{ml}$ wody destylowanej. Następnie płytki przykryto filtrem i wysiano nasiona roślin testowych - Triticum aestivum i Brassica napus w ilości 6 szt./płytkę. Wybór roślin testowych podyktowany był potrzebą sprawdzenia możliwości uprawy tradycyjnych roślin rolniczych, po ewentualnym zlikwidowaniu plantacji drzew. Tak przygotowane biotesty inkubowano w pozycji pionowej, w temperaturze $25^{\circ} \mathrm{C}$ bez dostępu światła przez 96 godzin. Pierwszej oceny kiełkowania nasion pszenicy ozimej oraz rzepaku ozimego dokonano po $24 \mathrm{~h}$ od momentu założenia biotestu, a kolejne odczyty przeprowadzano po 48, 72 i 96 h, rejestrując obraz pojedynczej płytki testowej przy pomocy aparatu cyfrowego. Po $96 \mathrm{~h}$ od momentu założenia biotestu, dokonano pomiarów długości korzeni i hipokotylu, wykorzystując program analizy obrazu Image Tools.

Tabela 1. Charakterystyka podłoża

Table 1. Characteristics of the substrate

\begin{tabular}{l|c|c|c}
\hline \multirow{2}{*}{$\mathrm{pH}(1 \mathrm{M} \mathrm{KCl})$} & $\mathrm{G}-1$ & $\mathrm{G}-2$ & $\mathrm{G}-3$ \\
\cline { 2 - 4 } & 6,90 & 6,45 & 6,40 \\
\hline Typ podłoża & \multicolumn{2}{|c}{ piasek gliniasty + podłoże ogrodnicze $(2: 1)$} \\
Substrate type & \multicolumn{3}{|c}{$<$ sandy loam + garden substrate $(2: 1)$} \\
\hline $\mathrm{C}_{\text {org }}[\%]$ & \multicolumn{3}{|c}{$<20$} \\
\hline
\end{tabular}

G-1 - gleba kontrola, G-2 - gleba spod rocznej plantacji Oxytree, G-3 gleba spod dwuletniej plantacji Oxytree

G-1 - control soil, G-2 - soil from 1 year old Oxytree plantation, G-3 - soil from 2 years old Oxytree plantation

Biotest przeprowadzono w 3 niezależnych seriach, po 3 powtórzenia $\mathrm{w}$ serii. Uzyskane wyniki opracowano staty- 
stycznie w programie ARM 2018, określając istotność różnic testem Studenta-Newmana-Keulsa, przyjmując poziom istotności $\alpha=0,05$.

\section{Wyniki i dyskusja / Results and discussion}

Wyniki badań nie wykazały istotnych różnic w kiełkowaniu roślin testowych, niezależnie od wieku plantacji. Jedynie w początkowym okresie (po $24 \mathrm{~h}$ ), rośliny rzepaku ozimego na glebie z 1-rocznej plantacji (G-2) kiełkowały słabiej niż na obiekcie kontrolnym (G-1), co zostało potwierdzone statystycznie. Obie rośliny testowe wykazały wysoką zdolność kiełkowania wynoszącą dla pszenicy ozimej od 96\% na obiektach badanych (G-2 i G-3) do 98\% na obiekcie kontrolnym (tab. 2). Dla rzepaku ozimego wartości te wynosiły od 89\% (G-2) do 94\% (G-1) (tab. 3). Otrzymane różnice pomiędzy poszczególnymi obiektami w zdolności kiełkowania, zarówno dla pszenicy ozimej, jak i rzepaku ozimego nie zostały jednak potwierdzone statystycznie (tab. 2, 3).

Przeprowadzone badania nie wykazały również istotnego wpływu gleby pobranej z okolic korzeniowych, zarówno 1-rocznych, jak i 2-letnich roślin Oxytree, na długość korzeni i części nadziemnych roślin testowych. W przypadku pszenicy ozimej najkrótsze korzenie $(63,7 \mathrm{~mm})$ stwier- dzono na obiekcie kontrolnym G-1, natomiast najdłuższe (67,7 mm) na obiekcie G-3. Podobną zależność obserwowano dla długości hipokotyli pszenicy ozimej (tab. 2). Natomiast korzenie rzepaku ozimego reagowały skróceniem długości na glebach testowych (G-2 i G-3) odpowiednio o 10,8 i $8,9 \mathrm{~mm}$, jednak nie zostało to potwierdzone statystycznie. Hipokotyl rzepaku ozimego największą długość (48,3 mm) osiągnął na obiekcie z glebą spod 2-letnich roślin Oxytree (G-3), natomiast najmniejszą (38,1 mm) na glebie spod roślin 1-rocznych (G-2). Wartości te nie różniły się istotnie od uzyskanych na obiekcie kontrolnym (tab. 3).

Pomimo ograniczonego obszaru oddziaływań, uwalniane do gleby wydzieliny korzeniowe mogą odgrywać istotną rolę $\mathrm{w}$ interakcjach pomiędzy organizmami. Istotną rolą eksudatów jest wpływ roślin na mikroorganizmy glebowe. Substancje te mogą m.in. inicjować symbiozę z bakteriami Rhizobium lub grzybami mikoryzowymi, a także utrzymywać specyficzną dla danego gatunku rośliny różnorodność mikroorganizmów (Badri i Vivanco 2009). Inną ważną funkcją wydzielin korzeniowych mogą być interakcje pomiędzy roślinami wyższymi na poziomie: donor - akceptor. Działanie stymulujące kiełkowanie i wzrost pasożytniczych chwastów z rodzaju zaraza - Orobanche crenata, Orobanche ramosa i Orobanche foetida, pod wpływem wydzielin z rośliny żywicielskiej Trigonel-

Tabela 2. Wpływ gleby na kiełkowanie i początkowy wzrost pszenicy ozimej

Table 2. Influence of soil on germination and preliminary growth of winter wheat

\begin{tabular}{|c|c|c|c|c|c|c|}
\hline \multirow{2}{*}{$\begin{array}{l}\text { Obiekt } \\
\text { Object }\end{array}$} & \multicolumn{4}{|c|}{$\begin{array}{l}\text { Skiełkowane nasiona pszenicy ozimej \% } \\
\text { Seed germination of winter wheat in \% }\end{array}$} & \multirow{2}{*}{$\begin{array}{l}\text { Długość korzeni } \\
\text { Root length } \\
{[\mathrm{mm}]}\end{array}$} & \multirow{2}{*}{$\begin{array}{c}\text { Długość hipokotyli } \\
\text { Hypocotyl length } \\
{[\mathrm{mm}]}\end{array}$} \\
\hline & $24 \mathrm{~h}$ & $48 \mathrm{~h}$ & $72 \mathrm{~h}$ & $96 \mathrm{~h}$ & & \\
\hline G-1 & $2 \mathrm{a}$ & $93 \mathrm{a}$ & $98 \mathrm{a}$ & $98 \mathrm{a}$ & $63,7 \mathrm{a}$ & $15,1 \mathrm{a}$ \\
\hline $\mathrm{G}-2$ & $4 \mathrm{a}$ & $94 \mathrm{a}$ & $96 \mathrm{a}$ & $96 \mathrm{a}$ & $65,7 \mathrm{a}$ & $16,7 \mathrm{a}$ \\
\hline G-3 & $2 \mathrm{a}$ & $91 \mathrm{a}$ & $96 \mathrm{a}$ & $96 \mathrm{a}$ & $67,7 \mathrm{a}$ & $19,1 \mathrm{a}$ \\
\hline $\begin{array}{l}\operatorname{NIR}(0,05) \\
\operatorname{LSD}(0.05)\end{array}$ & 3,7 & 10,2 & 4,5 & 4,5 & 7,41 & 4,01 \\
\hline
\end{tabular}

G-1 - gleba kontrola, G-2 - gleba spod rocznej plantacji Oxytree, G-3 - gleba spod dwuletniej plantacji Oxytree

G-1 - control soil, G-2 - soil from 1year old Oxytree plantation, G-3 - soil from 2 years old Oxytree plantation

Tabela 3. Wpływ gleby na kiełkowanie i początkowy wzrost rzepaku ozimego

Table 3. Influence of soil on germination and preliminary growth of winter rape

\begin{tabular}{|c|c|c|c|c|c|c|}
\hline \multirow{2}{*}{$\begin{array}{l}\text { Obiekt } \\
\text { Object }\end{array}$} & \multicolumn{4}{|c|}{$\begin{array}{l}\text { Skiełkowane nasiona rzepaku ozimego \% } \\
\text { Seed germination of winter rape in } \%\end{array}$} & \multirow{2}{*}{$\begin{array}{l}\text { Długość korzeni } \\
\text { Root length } \\
{[\mathrm{mm}]}\end{array}$} & \multirow{2}{*}{$\begin{array}{c}\text { Długość hipokotyli } \\
\text { Hypocotyl length } \\
{[\mathrm{mm}]}\end{array}$} \\
\hline & $24 \mathrm{~h}$ & $48 \mathrm{~h}$ & $72 \mathrm{~h}$ & $96 \mathrm{~h}$ & & \\
\hline G-1 & $39 \mathrm{a}$ & $92 \mathrm{a}$ & $94 \mathrm{a}$ & $94 \mathrm{a}$ & $68,5 \mathrm{a}$ & $41,9 \mathrm{a}$ \\
\hline G-2 & $30 \mathrm{~b}$ & $87 \mathrm{a}$ & $89 \mathrm{a}$ & $89 a$ & $57,7 \mathrm{a}$ & $38,1 \mathrm{a}$ \\
\hline G-3 & $33 \mathrm{ab}$ & $87 \mathrm{a}$ & $91 \mathrm{a}$ & $92 \mathrm{a}$ & $59,6 \mathrm{a}$ & $48,3 \mathrm{a}$ \\
\hline $\begin{array}{l}\operatorname{NIR}(0,05) \\
\operatorname{LSD}(0.05)\end{array}$ & 6,3 & 17,2 & 12,8 & 11,8 & 15,02 & 13,26 \\
\hline
\end{tabular}

G-1 - gleba kontrola, G-2 - gleba spod rocznej plantacji Oxytree, G-3 - gleba spod dwuletniej plantacji Oxytree G-1 - control soil, G-2 - soil from 1year old Oxytree plantation, G-3 - soil from 2 years old Oxytree plantation 
la foenum-graecum zaobserwowali Fernandez-Aparicio i wsp. (2008). Natomiast Al-Sherif i wsp. (2013) wykazali, że uwalniane z korzeni Brassica nigra allelopatyny wpływały inhibicyjnie na kiełkowanie Triticum aestivum, Phalaris paradoxa, Trifolium alexandrinum i Sisymbrium irio. Podobnie Otusanya i wsp. (2014) zaobserwowali hamujący wpływ eksudatów z korzeni Tithonia diversifolia na kiełkowanie Amaranthus dubius i Solanum melongena. Badanie to wykazało, że działanie allelozwiązków uwalnianych z korzeni jest zależne od gatunku rośliny docelowej (akceptora). Wpływ na wzrost i zawartość chlorofilu roślin akceptorowych był różny. Wzrost $A$. dubius był zahamowany, a zawartość chlorofilu wyższa niż na kontroli, natomiast S. melongea nie zareagowała zmianami tych parametrów. Z badań przeprowadzonych przez Kaur i wsp. (2014) wynika, że potencjał allelopatyczny donorów, jest uwarunkowany typem gleby, zawartością materii organicznej oraz aktywnością mikrobiologiczną gleby.

Uzyskane wyniki badań własnych nie wykazały statystycznie istotnej aktywności allelopatycznej gleby pochodzącej z bezpośredniego sąsiedztwa korzeni Oxytree (niezależnie od wieku plantacji) w odniesieniu do roślin testowych. Zaobserwowane zmiany długości korzeni i części nadziemnych rzepaku ozimego i pszenicy ozimej w porównaniu do obiektu kontrolnego nie zostały potwierdzone statystycznie. $Z$ uwagi na istnienie szeregu czynników (bio- tycznych i abiotycznych) warunkujących allelopatyczne oddziaływanie roślin, na tym etapie badań nie można wykluczyć istnienia bądź braku potencjału allelopatycznego Oxytree.

\section{Wnioski / Conclusions}

1. Nasiona pszenicy ozimej i rzepaku ozimego na obiektach z glebą spod Oxytree kiełkowały słabiej w porównaniu do obiektu kontrolnego. Różnice te nie zostały jednak potwierdzone statystycznie.

2. Wiek plantacji (roczna czy dwuletnia) nie miał istotnego wpływu na zdolność kiełkowania nasion, długość korzeni i hypokotyli pszenicy ozimej i rzepaku ozimego.

\section{Podziękowanie / Acknowledgements}

Autorzy składają podziękowanie firmie Oxytree Solutions Poland Sp. z o.o. za udostępnienie materiału do badań.

Praca wykonana w ramach zadania 2.3 Programu Wieloletniego Instytutu Uprawy Nawożenia i Gleboznawstwa Państwowego Instytutu Badawczego, finansowanego przez Ministerstwo Rolnictwa i Rozwoju Wsi.

\section{Literatura / References}

Al-Sherif E., Hegazy A.K., Gomaa N.H., Hassan M.O. 2013. Allelopathic effect of black mustard tissues and root exudates on some crops and weeds. Planta Daninha 31 (1): 11-19. DOI: 10.1590/S0100-83582013000100002.

Badri D.V., Vivanco J.M. 2009. Regulation and function of root exudates. Plant, Cell \& Environment 32 (6): 666-681. DOI: 10.1111/ j.1365-3040.2009.01926.x.

Bortniak M., Sekutowski T. 2009. Wpływ wodnych wyciągów glebowych spod 1 i 2 letniej uprawy mozgi trzcinowatej (Phalaris arundinacea) na długość korzeni gorczycy białej (Sinapis alba). s. 503-508. W: „Wielokierunkowość badań w rolnictwie i leśnictwie” t. 2 (B. Wiśniowska-Kielian, red.). Wydawnictwo Uniwersytetu Rolniczego w Krakowie, 389 ss. ISBN 978-83-60633-34-2.

Fernandez-Aparicio M., Andolfi A., Evidente A., Perez-de-Luque A., Rubiales D. 2008. Fenugreek root exudates show species-specific stimulation of Orobanche seed germination. Weed Research 48 (2): 163-168. DOI: 10.1111/j.1365-3180.2007.00609.x.

Gniazdowska A., Oracz K., Bogatek R. 2004. Allelopatia - nowe interpretacje oddziaływań pomiędzy roślinami. [Allelopathy - new interpretations of plant - plant interactions]. Kosmos 53 (2): 207-217.

Kaur R., Callaway R.M., Inderjit 2014. Soils and the conditional allelopathic effects of a tropical invader. Soil Biology and Biochemistry 78: 316-325. DOI: 10.1016/j.soilbio.2014.08.017.

Marczewska-Kolasa K., Sekutowski T., Bortniak M. 2012. Wykrywanie potencjału allelopatycznego nasion Centaurea cyanus za pomocą biotestów. [Determination of allelopathy Centaurea cyanus seeds by using bioassays]. Progress in Plant Protection/Postępy w Ochronie Roślin 52 (3): 733-736. DOI: 10.14199/ppp-2012-127.

Opinia Państwowej Rady Ochrony Przyrody dotycząca dopuszczalności tworzenia na terenie Polski plantacji rośliny Oxytree (Paulownia Clon in Vitro $112^{\circledR}$ ), jej możliwego wpływu na środowisko naturalne oraz zasadności obejmowania akcji jej sadzenia patronatem Ministra Środowiska. PROP/KOR/2016-01-ws. Warszawa, 26 stycznia 2016 r.

Otusanya O.O., Sokan-Adeaga A.A., Ilori O.J. 2014. Allelopathic effect of the root exudates of Tithonia diversifolia on the germination, growth and chlorophyll accumulation of Amaranthus dubius L. and Solanum melongena L. Research Journal of Botany 9 (2): $13-23$. DOI: $10.3923 / \mathrm{rjb} .2014 .13 .23$.

PHYTOTOXKIT 2004. Seed germination and early growth microbiotest with higher plants. Standard Operational Procedure. Belgium. MicroBioTest Inc, 24.

Raport 2013. Testy pod względem odrębności, stabilności i jednolitości (DUS) Hibrid Paulownia elongata $\times$ Paulownia fortunei. Raport o Paulownia Clon in Vitro $112^{\circledR}$. Instytut Badań Energetyki Odnawialnej, Wydział Technologii Agroleśnictwa i Nauki oraz Genetyki, Uniwersytet Castilla-La Mancha. http://docs.csglobal.pro/oxytree/oxytree-dus_report-PL.pdf [dostęp: 11.05.2018].

Sekutowski T., Sadowski J. 2009. Phytotoxkit ${ }^{\mathrm{TM}}$ microbiotest used in detecting herbicide residue in soil. [Wykorzystanie testu Phytotoxkit $^{\mathrm{TM}}$ w wykrywaniu pozostałości herbicydów w glebie]. Environment Protection Engineering 35 (1): 105-110. 